\title{
Mesterpedagógus SZakmai TANÁROK SZAKMAI ÉLETÚTJAI
}

\author{
BÜKKI ESZTER \\ ELTE Neveléstudományi Doktori Iskola
}

\begin{abstract}
Kutatásunkban 53 szakmai tanár mesterpedagógus pályázatának részeként elkészített szakmaiéletút-dokumentumait elemeztük, a szakmai fejlődés tanári értelmezésének és gyakorlatának, motivációinak és formáinak, illetve a tipikus szakmai tanári életútmintázatok, karrierutak feltérképezése érdekében. Eredményeink szerint a vizsgált tanárok szakmai fejlődésében a legfontosabb tanulási formát a formális képzések jelentik, mely elsősorban a rendszerszintű szabályozókkal magyarázható, ugyanakkor kiemelkedő szerepet játszanak a belső és külső kapcsolatok és a tanári együttmüködések is. E tanári tanulási lehetőségek esetenként az eredeti szakmában való munkavállaláshoz, de jellemzőbben iskolai és iskolán kívüli, tanításon felüli munkakörökhöz és feladatokhoz kapcsolódnak, melyek alapján tipikus szakmai tanári karrierutakat különböztethetünk meg.
\end{abstract}

Kulcsszavak: tanári folyamatos szakmai fejlődés, tanári életút, szakképzés

In our research we have analysed the career documents $(\mathrm{CVs})$ of 53 vocational teachers prepared as part of their application to become a 'master teacher', in order to investigate their understanding and practice, motivation for and forms of professional development and the typical patterns of vocational teacher career, career paths. Pursuant to our results, formal training is the most important form of professional development for these teachers, which can be explained mostly by system level regulations, however, internal and external relations and teacher cooperation also play an outstanding role. These teacher learning opportunities are linked in some cases to taking up work in the original vocation, but more often they are related to positions and tasks pursued within or outside the school, in addition to teaching, based on which typical vocational teacher career paths can be discerned.

Keywords: teacher continuous professional development, teacher career, vocational education and training

Levelező szerző: Bükki Eszter, ELTE PPK, 1075 Budapest, Kazincy utca 23-27.

E-mail: bukki.eszter@ppk.elte.hu 


\section{Bevezetés}

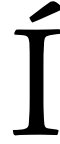
rásunkban a szakképzésben dolgozó mesterpedagógus szakmai tanárok által készített szakmaiéletút-dokumentumok tartalomelemzésének eredményeit mutatjuk be. ${ }^{1}$

Kutatásunk a pedagógusok folyamatos szakmai fejlődésének vizsgálatához kötődik, ami a nemzetközi és hazai oktatáskutatások kiemelt területévé vált az elmúlt két évtizedben. Köszönhető ez egyrészt a téma kiemelt szakpolitikai jelentőségének azon kutatási eredmények fényében, miszerint a tanulói teljesítményt az oktatáspolitika által is befolyásolható iskolán belüli tényezők közül elsősorban a tanári munka minősége határozza meg, amit jelentős mértékben befolyásol a tanárok munkába lépést megelőző és azt követő fejlődése (Villegas-Reimers 2003; Barber-Mourshed 2007; Barber-ChijoteMourshed 2010; Caena 2013). A tanári tanulás jelentőségét hangsúlyozzák továbbá az iskolafejlesztések, oktatási reformok, innovációk implementációját vizsgáló kutatások is (Fazekas-Halász 2012; Looi-Teb 2015). A folyamatos szakmai fejlődés (FSZF) alatt azonban ma már nem egyszerűen a munkába lépés előtti és azt követő formális képzést értjük, hanem a tanárok folyamatos, egész életen át tartó, iskolai munkahelyi környezetbe ágyazott és nagymértékben társas jellegű, formális, nem formális és informális tanulási tevékenységeket egyaránt magába foglaló szakmai tanulását (Scheerens 2010; Gilbert 2011; Webster-Wright 2009).

Kutatásunk a tanári FSZF kutatásának azon irányaihoz kapcsolódik szorosabban, melyek e szakmai fejlődés az életpálya egészén történő értelmezésében fontos szerepet szánnak a tanári biográfiák, szakmai életutak vizsgálatának és ezen belül a szakmaiéletút-narratívák elemzésének (Sikes-Measor-Woods 1985; Huberman-Grounauer-Marti 1993; Kelchtermans 1993, 2017; Korthagen 2004). A szakképzésben dolgozó szakmai tanárok folyamatos szakmai fejlődését nemzetközi és hazai szinten is viszonylag kevés kutatás vizsgálta, a nemzetközi kutatások azonban megerősítik a szakmai tanári életutak vizsgálatának jelentőségét a szakmai tanári professzionalizmus és identitásértelmezések feltárásában is (Robson-Bailey-Larkin 2004; Fejes-Köpsén 2014; Köpsén 2014).

Kutatásunk célja a mesterpedagógus szakmai tanárok által készített szakmaiéletút-dokumentumok tartalomelemzése volt a formális életpálya, a szakmai tanárrá válás útjai, az FSZF gyakorlata és az annak alapjául szolgáló motivációk és identitásértelmezések feltárása érdekében. Kutatási kérdéseink a következők voltak:

- Kiből és miért lesz szakmai tanár? Mi az eredeti végzettség, mik a tanári pályára lépés motivációi?

- Hogyan értelmezik szakmai fejlődésüket? Mi az FSZF motivációja, fő formái és területe? Milyen tipikus karrierutak léteznek a szakmai tanárok számára?

- Fenntartanak-e kapcsolatot a gazdasággal, eredeti szakmájukkal, és ha igen, milyen formában?

- Milyen egyéb külső kapcsolatokat tartanak még fent, és az hogyan hat szakmai fejlödésükre?

1 Írásunk az ELTE PPK Neveléstudományi Intézetében folyó „A mester- és kutatópedagógusok tevékenységének hatása a köznevelés fejlesztésére" c. kutatáshoz kapcsolódik, ami a pedagógusminősítési rendszer kiegészítését célzó pilot projekt során 2015 tavaszán készített mesterprogramok és kapcsolódó dokumentumok elemzését tűzte ki célul. A tanulmány elkészítését az Emberi Erőforrások Minisztériuma ÚNKP17-3 kódszámú Új Nemzeti Kiválósági Programja támogatta. 
Előfeltevésünk az volt, hogy e mesterpedagógus pályázat részeként, az Oktatási Hivatal $(\mathrm{OH})$ által meghatározott szempontok alapján elkészült dokumentumok alkalmasak lehetnek e kérdések megválaszolására, hiszen az OH 2016. évi Útmutatójának ${ }^{2}$ meghatározásában a "Szakmai életút bemutatása és elemzése” egy olyan „összefüggo írásmü, amelyben a mesterpedagógus-jelölt összegző igénnyel bemutatja szakmai életútjának legfontosabb állomásait, szakmai fejlödésének ivét, értékeli szakmai tevékenységeit a Mesterpedagógus négydimenziós tevékenységmodellje mentén" (e négy dimenzió: tudatos szakmai fejlődés, feltáró-elemző, fejlesztő-újító és tudásmegosztó-segítő tevékenységek). E 6-10 oldal javasolt terjedelmü dokumentum célja „a mesterpedagógus-jelölt szakmai önértékelésének elkészitése annak érdekében, hogy igazolja, alátámassza kimagasló felkészültségét". A pályázó az eddigi mesterpedagógus-tevékenységek bemutatása során az $\mathrm{OH}$ által megadott segítő szempontok szerint kitérhet e tevékenységek hatókörére, a megvalósításukhoz kapott támogatásra, a tapasztalt nehézségekre és az igényelt/tervezett jövőbeli fejlődés területeire is.

\section{A mesterpedagógus szakmai tanárok szakmai életpályája}

Kutatásunkban 53 mesterpedagógus szakmai tanár szakmaiéletút-dokumentumait elemeztük részben (a formális jellemzőkre és életpályára vonatkozóan) manuális kódolás, részben az atlas.ti kvalitatív tartalomelemző szoftver segítségével. A szövegek kódolása a szakirodalom alapján előzetesen meghatározott kódokból indult, a további kódok kialakítása a szövegek interpretációja során történt. A vizsgált dokumentumok az $\mathrm{OH}$ előzetesen megadott azonos szempontrendszere ellenére meglehetős változatosságot mutattak mind a terjedelem (3-15 oldal), mind a tartalmi részletezettség és mélység (formális versus szubjektív, magyarázó-értelmező jelleg) tekintetében, ezért kutatási kérdéseinket nem sikerült maradéktalanul megválaszolni. Az alábbiakban elemzésünk eredményeiről számolunk be.

\section{A vizsgált szakmai tanárok formális jellemzői}

A vizsgálatban részt vevő mesterpedagógus szakmai tanárok a középkorú/idősebb korosztályhoz tartoznak (közel kétharmaduk 38-54 éves, a többi, 19 tanár 55 évesnél idősebb), a nemek aránya (fele-fele) ugyanakkor nagyjából megfelelt az iskolai rendszerű szakképzésben dolgozó szakmai tanárok nem szerinti megoszlásának. ${ }^{3}$ A többség 20-30 év tanítási gyakorlattal rendelkezett a pályázat beadásakor, ugyanakkor e pilot program résztvevői közül viszonylag sokan (13 fö) 20 évnél kevesebb időt töltöttek el tényleges tanítással életpályájuk során.

2 Oktatási Hivatal (2016) Útmutató a Mesterpedagógus fokozatot megcélzó minősítési eljáráshoz. https:// www.oktatas.hu/pub_bin/dload/kiadvanyok/mesterpedagogus_utmutato.pdf [Letöltve: 2018. 06. 05.]

3 Az 53 tanár közül 27 fö volt nő, míg a 2016. októberi adatok szerint összességében 47,6\% a nők aránya a szakmai tanárok/szakoktatók között a szakképző iskolák 9-12. évfolyamán (51,1\% a szakgimnázium szakképző évfolyamain), magasabb a szakmai elméleti (54,3\%, illetve 57,7\%) és alacsonyabb a szakmai gyakorlati (39,5\%, illetve 41,8\%) tárgyakat oktató tanárok között. Az adatok forrása: Oktatási Hivatal. Köznevelési statisztika - KIR-STAT2016 Aggregátor rendszer. http://www.kir.hu/stat16aggr [Letöltve: 2018.06.05.] 
A vizsgált tanárok túlnyomó többsége szakmai tanári végzettséggel rendelkezett, egy fö szakoktatói, valamit két-két fö emellett közismereti, illetve számítástechnikai tanári végzettséggel is. Szinte mind valamilyen szintű vezetői pozíciót is betöltött iskolájában: a többség (24 fö) igazgatóhelyettesként dolgozott, kilenc fö igazgatóként, tizennégyen pedig munkaközösség-vezetők voltak a pályázat beadásának időpontjában. E tanárok többsége 2015-ben is a legelső munkahelyén, iskolájában dolgozott (21 fö több mint 20 éve).

\section{A szakmai tanárrá válás útjai}

A formális életutak elemzése alapján a vizsgált tanárok kevéssel több mint a fele (28fó) rövidebb-hosszabb szakmai (szakmaterületi) karrier után lépett a tanári pályára. E csoportba tartozók többsége (18 fö) eredetileg csak szakmai felsőfokú (a nők inkább föiskolai, a férfiak egyetemi) végzettséget szerzett (továbbá 3 fö szakképesítést), a többi 7 tanár eredeti szakmai végzettségével párhuzamosan szerezte meg a tanári képesítést is. E karrierút jellemzőbb a nők körében, akik továbbá nagyobb arányban (10 fö) hoszszabb, 6-15 év szakmaterületi munka után váltottak pályát, egy fó 20 , hat fó viszont csupán egy-két évet dolgozott eredeti szakmájában. A mintában szereplö férfi tanárok kisebb része (11 fö) tartozik e csoportba, akiknek fele 6-10 éves szakmai karrier után lépett a tanári pályára. E tanárok jellemzően rögtön teljes állásban kezdték meg tanári pályájukat, bár néhányan előtte már a szakmai munka mellett óraadó tanárként is dolgoztak néhány évet vagy előbb a felnőttképzésbe, esetleg felsőoktatásba kapcsolódtak be. Többségük a tanári munka megkezdését követő pár éven belül szerezte meg szakmai tanári képesítését.

A szakmai tanárrá válás másik útját a felsőfokú képzés elvégzése után azonnal tanári pályára lépés jelentette, bár az e csoportba tartozó mintegy 25 tanár közül is heten eredetileg csak szakmai végzettséget szereztek, további 7 fó pedig eredetileg közismereti és/vagy számítástechnikai tanárként végzett és kezdett tanítani. Ők a szakmai tanári képesítést csak később, munkahelyi (pl. iskolai profilváltás) vagy szakmai fejlődési (pl. nyelvtanári munka támogatása) igények/elvárások miatt szerezték meg.

Kutatási kérdéseink között szerepelt a tanári pályára lépés motivációinak feltárása, a vizsgált szakmaiéletút-dokumentumok többsége azonban nem tért ki erre a kérdésre. Azok a tanárok, akik említettek motívumokat, túlnyomó többségben (15 fö) azt hangsúlyozták, hogy eleve tanárnak készültek, néhányan kiemelve a családi hagyományok, de különösen a volt szakképző iskola és tanárok vagy a főiskolai tanárok ösztönzését és/vagy példáját: „A középiskola utolsó évfolyamán tanultam, amikor véglegesen eldöntöttem, hogy tanár szeretnék lenni. Tanáraim szaktudását, müveltségét, attitüdjét példamutatónak, követendönek tartottam.” Vagy: „Középiskolai szakmai tanárom javasolta, hogy gondolkodjak továbbtanulásban, szívesen látnának szakmai oktatóként korábbi iskolámban.” A vizsgált tanárok közül 14 fó említette, hogy középfokon szakképző iskolában végzett, és többen voltak, akik egykori iskolájukba tértek vissza tanítani, ami az egyes iskolákban többé-kevésbé tudatosan végzett szakmai tanári utánpótlás-nevelésre utal. Három női tanár jelölte meg a gyerekvállalást karrierváltása indokául, míg két férfi tanár a szakmában való munkavállalási nehézségeket említette. 


\section{A szakmai tanárok folyamatos szakmai fejlödése}

A vizsgált szakmaiéletút-dokumentumok szerint mind a formális, mind az informális tanulás ${ }^{4}$ fontos szerepet játszik a szakmai tanárok szakmai fejlődésében. A formális tanulási tevékenységek jelentős részét elsősorban a jogszabályi feltételeknek, a képesítési és továbbképzési előírásoknak való megfelelés motiválta. Ilyen formális tanulás mindenekelőtt a tanári képesítés megszerzését vagy a főiskolai végzettség egyetemi szintre emelését célzó tanárképzési programokban való részvétel, hiszen a vizsgált 53 tanár közül mindössze 18 fönek volt az elsőként megszerzett végzettsége szakmai tanári vagy szakoktatói képesítés (is). A formális tanulás egy, a szakmaiéletút-dokumentumokban igen hangsúlyosan megjelenő területét jelentik az iskolán belüli vagy azon kívüli vezetői, illetve országos hatókörű oktatásirányítási, szakmai szolgáltatási vagy fejlesztési, innovációs tevékenységek gyakorlásának jogszabályi előfeltételét jelentő felkészítő és továbbképzések. Ilyen különösen a felsőoktatásban megszerezhető pedagógus szakvizsga, melyet a vizsgált tanárok fele (26 fő) megszerzett. Jelentős továbbá az érettségi és szakmai vizsgaelnöki, szakmai szakértői és szaktanácsadói tevékenységek gyakorlásához kapcsolódó, az Oktatási Hivatal, a Nemzeti Szakképzési és Felnőttképzési Hivatal (és jogelödjei) és a gazdasági és iparkamarák által szervezett képzésekben részt vevők aránya. Ez nem meglepő annak fényében, hogy a vizsgált tanárok több mint fele (28 fö) szerepel az országos szakmai és/vagy felnőttképzési szakértői, ötöde (11 fö) a szaktanácsadói listán, míg 25 fö szakmai vizsgaelnöki, 20 fö pedig érettségi vizsgaelnöki feladatokat is ellát (néhányan e jegyzékek közül többen is szerepelnek). Végül a formális képzések egy másik jellegzetes típusát az akkreditált és/vagy fejlesztési programokhoz kapcsolódó tanártovábbképzések jelentik, melyek jellemzően módszertani és általánosabb pedagógiai témákhoz kapcsolódtak.

$\mathrm{A} z$ életút-dokumentumok szerint e formális képzések azonban meglehetősen kevés lehetőséget nyújtanak a szakmai tanárok számára szakmaterületi tudásuk és készségeik fejlesztéséhez vagy éppen egy új szakma/tantárgy tanítására való felkészüléshez. Ez elsősorban a technológia-gazdák, gyártók professzionális/gyári képzésein, bemutatóin való részvétel, illetve a szakirodalom-olvasás, konferencia-és kiállítás-látogatás, helyi vagy országos szakmai szervezetekben való részvétel által történő folyamatos önképzés által valósul meg: „Kezdetben meglévő akadályokat le tudtam küzdeni. A szolgáltató szakma elméleti tantárgyainak tanitásához tulajdonképpen semmilyen felsőoktatási intézményben nem képeznek tanárokat, ezért a meglévő kémiai, anatómiai tudásomat kellett egy speciális szakmára vonatkozó (fodrász, kozmetikus) képzésénél meglévő szakmai tantárgyakra alkalmazni." Jelentős informális tanulási lehetőséget jelent a szakmai tanárok számára továbbá a nemzetközi és országos/iskolai fejlesztési és/vagy mobilitási projektekben való részvétel is: tizennégy dokumentum említi a külföldi tanulmányúton vagy fejlesztési projektben, kilenc a 2000-es évek Szakiskolai Fejlesztési Programjában (SZFP) való részvétel jelentőségét a szakmai fejlődés szempontjából, de a pályázatírásban való aktív részvétel általában is e tanárok nagy többségére jellemző. Másféle külső kapcsolatok kiépítésére és informális tanulásra adhat lehetőséget a felnőttképzésben való részvétel oktatóként, illetve ehhez kapcsolódóan tananyagfejlesztőként vagy (program- és intézményakkreditációs/ellenőrző tevékenységet végző) felnőttképzési szakértőként, ami a

\footnotetext{
4 A formális és informális tanulást a strukturáltság és szándékoltság dimenziói mentén egy kontinuum két
} végpontjaként értelmezzük Kyndt-Gijbels-Grosemans-Donche (2016) meghatározásával összhangban. 
vizsgált életutak jelentős részében megjelenik - mintegy 27 fö említette, hogy jelenleg vagy alkalmanként tanít felnőttképzésben is, beleértve piaci alapú és munkaerő-piaci, közfoglalkoztatotti képzéseket is: „Párbuzamos kitérőként ekkor egy budapesti nagyvállalatnál is vállaltam munkát - a vezetöket tanítottam számitógép-kezelésre - aminek jelentös pozitiv hozadéka volt: két osztályunk számviteles osztály volt, a cég már váltott számitógépes ügyvitelre, elsö kézböl tudhattam meg, milyen tudást is várnának el a hozzájuk belépö kezdőktöl”; "Talán nem kell mondanom, hogy mennyivel más pedagógiai helyzet egy, az oktatásért jelentös összeget fizetö, többször magas szintü gyakorlati tapasztalattal rendelkezö (idei csoportban van raktárvezetö, logisztikai vezetö is, mindkettö milliárdos árbevételü cégtől) hallgató oktatása és eredményes vizsgáig történő eljuttattatása, mint a sokkal kisebb motivációval rendelkezö érettségizett fiatalé. Viszont így én is rengeteg gyakorlati tapasztalathoz jutok a logisztika és a külkereskedelem területén, amit máshol is jól tudok basznositani"; "Felnöttképzési szakértőként a belyszini szemlék alkalmát szintén alkalmasnak tartom a tudás megosztására, tapasztalatok cseréjére, jó gyakorlatok megismerésére, megismertetésére". Továbbá, míg az országos hatókörű vizsgaelnöki, szakértői és szaktanácsadói tevékenységek gyakorlásához kapcsolódó formális képzések elsősorban oktatásirányítási kérdésekre és jogszabályváltozások nyomon követésére fokuszálnak, több tanár is hangsúlyozta az e tevékenységek gyakorlásából, a más iskolák más tanáraival való találkozásból és tapasztalatcseréből adódó informális tanulási lehetőséget: "A vizsgáztatói feladatok vállalása mögött egy olyan indittatás búzódik meg, hogy így lehetöségem van betekinteni más intézmények munkájába. A megszerzett tapasztalatokat pedig be tudom épiteni a mindennapi munkámba."

A szakmai fejlődés ösztönzői között megjelenik az intrinzik motiváció, a ,jobbat akarás” („mindig fontosnak éreztem, hogy mind a szaktudományban, mind a neveléstudományban folyamatosan fejlödjek”) és „a szakma követelménye” ("Munkám megköveteli az állandó tanulást mind magyar, mind idegen nyelvü anyagokból"; "A szakmánk jellegéböl adódóan állandóan fejlesztenünk kell elméleti és gyakorlati ismereteinket"). Ugyanakkor az életútdokumentumokban említett szakmai fejlődés jelentős részben a jogszabályi feltételeknek való megfeleléshez (lásd fent a formális képzésröl írottakat), illetve a szakképzés szinte „állandósult”, országos szintű szerkezeti és tartalmi reformjaihoz és/vagy iskolai szintű változásaihoz (profilváltás, új szakma/tantárgy tanítása saját indíttatásra vagy iskolai ösztönzésre) kötődik. Az 1990-es évektől kezdődő többszörös képzésszerkezeti átalakulások, a szakképesítések, szakmai és vizsgakövetelmények és kerettantervek szinte folyamatos szerkezeti és tartalmi változásai egy állandó „innovációs kényszert” jelentenek a szakmai tanárok számára: „Az egészségügyi szakképzés, mióta pedagógus vagyok a hetedik képzési program változását éri meg"; „Továbbra is tervezem folytatni az eddigi innovációs tevekénységet, a szakképzés folyamatos átalakitása állandó reagálást és fejlesztést igényel".

A vizsgált szakmai tanárok jelentős része (mintegy 24 fö) országos hatókörű fejlesztési feladatokban és/vagy tankönyvfejlesztésben, valamint vizsga- és versenyfeladatok készítésében részt vevő, ezáltal pedig a szakképzésért és felnőttképzésért felelős minisztérium háttérintézményével, a kamarával és a munkáltatói szakmai szervezetekkel kapcsolatba kerülő szakértő/szaktanácsadó. E fontos mesterpedagógus szakmai tanári karrierút mellett további (egymást azonban nem kizáró) típusokat azonosítottunk, melyekhez jellegzetesen eltérő szakmai fejlődési motivációk, célok és lehetőségek kapcsolódhatnak: 
- az országos hatókörű oktatásirányítási feladatok ellátásában részt vállaló szaktanácsadók és érettségi vagy szakmai vizsgaelnökök, akik számára (mint azt fent említettük) informális tanulási lehetőséget biztosíthatnak az e tevékenység során létesített külső kapcsolatok;

- a felsőoktatáshoz szorosabban kötődő, a tanárképzésben oktatói, szakdolgozat témavezetői/bírálói vagy mentortanári feladatokat ellátó, vagy (kevés esetben) közös innovatív projektben részt vevő tanárok;

- intézményvezetők;

- a helyi tantervek, tananyag fejlesztésében, nemzetközi projektekben részt vevő vagy néhány esetben a helyi vállalatokkal való kapcsolattartás újszerű módjait fejlesztő iskolai szintű innovátorok; valamint

- az iskolai rendszeren kívüli felnőttképzésbe oktatóként és/vagy program/intézményakkreditációs szakértőként bekapcsolódó tanárok.

A vizsgált szakmai tanárok szakmával való kapcsolattartásának különböző módjait jelenti tehát:

- az országos fejlesztésekben való részvétel;

- az országos vagy helyi szakmai szervezetekhez való csatlakozás (pl. a turizmus, a gasztronómia területén);

- a helyi vállalatokkal és kamarával kapcsolatot tartó gyakorlati oktatásvezetői munka (mely néhány év szünet után újra hivatalos tisztségnek számít az iskolákban, bár szakmánként és intézményenként nagyon eltérő intenzitásúak lehetnek e kapcsolatok: az egészségügyben például néhány iskolában még a gyakorlati oktatók továbbképzését is felvállalják); illetve

- a felnőttképzésben való részvétel.

A tanári munka mellett a vizsgált tanárok csak kisebb része (14 fö) folytatott párhuzamosan szakmaterületi munkát is (vállalkozás fenntartásával vagy eseti megbízások elvállalásával), illetve két olyan személy is volt, aki pár évre otthagyta a tanári pályát és szakmai karriert épített, majd újra visszatért a tanításhoz. E tanárok azonban meghatározó jelentőségűnek tartják a tanári pályára lépést megelőzően vagy a tanítással párhuzamosan végzett szakmaterületi munkát a szakmai tanári munkában és fejlődésben: „A tanitás mellett vállalkozóként adóbevallásokat is készitettem, egyéni vállalkozók könyvelési feladatait láttam el. A gyakorlati élet tapasztalatai nagyon jól szolgálták az oktatási tevekénységet, az ismereteim folyamatos bövitését. Véleményem szerint csak úgy lehet egy szakmát tanitani, ba közben müveli is az ember”; "A szakmai fejlödésnek fontos szerepeként nemcsak tanitom a müszaki felülvizsgálati ismereteket, hanem gyakorlom is, így naprakész ismereteket tudok diákjaim számára átadni, és a bozott példáim sem iskolaszagúak, banem valós szakmai hátteret mutatnak"; "A tanitás mellett van vállalkozásom is, abol voltak oktatási feladataim (más iskolában, valamint felnöttoktatás), illetve autós diagnosztikai müszereket, elektronikai berendezéseket javitok, készitek, tervezek, így tanárként nem szakadtam el az ipartól sem, az órákon ténylegesen az életböl vett példákat tudok használni! Ezeket az ismereteimet kihasználom szemléltetö eszközök, vizsga-és versenyfeladatok készitésénél is". 


\section{Összegzés}

A kutatás eredményei alapján a vizsgált szakmai tanárok több mint fele rövidebb-hoszszabb szakmaterületi karrier után lépett a tanári pályára, és csak pár év elteltével szerezte meg a tanári képesítést, de csaknem ugyanennyien rögtön a tanári (vagy csupán felsőfokú szakmai) végzettségük megszerzése után kezdték meg tanári pályafutásukat. Az életút-dokumentumokból kirajzolódnak a mesterpedagógus szakmai tanárok tipikus karriertípusai: az országos fejlesztésekben részt vevő tanterv-/tananyag-/ tankönyvfejlesztő szakértők/szaktanácsadók, az országos oktatásirányítási feladatok ellátásában közremüködő vizsgaelnökök és szaktanácsadók, a felsőoktatással különböző minőségben (pl. oktató, konzulens/bíráló, mentor) és intenzitással kapcsolatokat fenntartó tanárok, az intézményvezetők, az iskolai szinten jelentős innovátor tevékenységet kifejtő, gazdasági és/vagy külföldi kapcsolatokat építő tanárok, valamint a külső kapcsolataikat a felnőttképzés irányában kiterjesztő tanárok. Folyamatos szakmai fejlődésükben meghatározók a formális képzések, mely elsősorban a rendszerszintű szabályozókkal magyarázható (munkaköri alkalmazási feltételek, továbbképzési rendszer). E fejlődésben ugyanakkor kiemelkedő szerepet játszanak a belső és külső kapcsolatok és a tanári együttműködések is, melyek megvalósulhatnak egyéni szakmaterületi munkavállalás során is, de jellemzőbben az iskolai és iskolán kívüli, tanításon felüli munkakörökhöz és feladatokhoz (pl. gyakorlati oktatásvezető, vizsgaelnök, szakértő, szaktanácsadó, mentortanár), illetve projektekben való részvételhez kapcsolódnak. E szakmai fejlődés fontos ösztönzője a belső fejlődési motiváció és a szakma gyors változásait követő tanulás szükségének felismerése, ugyanakkor nagyon jelentős a szakképzés szinte állandósult szerkezeti és tartalmi változásai által okozott „innovációs kényszer” is. Ez utóbbi azonban leginkább a központi, top-down reformok implementálásához és a szakképzés formális kereteinek (tantervek, tananyag, tankönyvek) folyamatos újraépítéséhez kötődik, és sokkal kevésbé jelenik meg az alulról jövő, a szakképzés gyakorlatának megújítását célzó bottom-up innováció.

Fenti eredményeink természetesen csak korlátozottan általánosíthatók a szakmai tanárok összességére, többek között azért, mert a vizsgált tanárok a szakma „elitjét” adó, a szakmai fejlődésben és tanári munkán kívüli tevékenységekben legaktívabb mesterpedagógusok csoportjába és a szakmai tanárok középkorú/idősebb generációihoz tartoznak. Másrészt, a formális életút mögötti mélyebb rétegek, motivációk értelmezésében figyelembe kell venni, hogy e dokumentumok tartalmát jelentősen meghatározta elkészítésük kontextusa, az explicit vagy vélt szakpolitikai elvárásokhoz való igazodás szándéka. A feltárt karrierutak és FSZF gyakorlat- és motivációs mintázatok mindazonáltal kiindulópontot nyújthatnak a többi korosztály és a nem mesterpedagógus tanárok szakmai fejlődésének elemzéséhez.

Kutatásunkat szakmai tanárokkal készítendő szakmaiéletút-interjúk készítésével folytatjuk, melynek során a tanári pályára lépés és a folyamatos szakmai fejlődés motivációi, a szakmai tanári identitás értelmezés és a fejlődést támogató és korlátozó szervezeti tényezők mélyebb szintű feltárására törekszünk. 


\section{IRODALOM}

Barber, M., Chijoke, Ch. \& Mourshed, M. (2010) How the World's Most Improved School Systems Keep Getting Better. Chicago, McKinsey \& Company.

Barber, M. \& Mourshed, M. (2007) How the World's Best Performing School Systems Come out on Top. Chicago, McKinsey \& Company.

Caena, F. (2013) Policies on Teachers' Continuing Professional Development (CPD): Balancing Provision with the Needs of Individual Teachers, Schools and Education Systems. Report of a Peer Learning Activity in Vienna, Austria 2-6 June 2013.

Fazekas Á. \& Halász G. (2012) Az implementáció világa. Az európai uniós forrásokból megvalósitott magyarországi oktatásfejlesztési beavatkozások empirikus vizsgálatának elméleti megalapozása. ELTE PPK Felsőoktatás-menedzsment Intézeti Központ. Kézirat.

Fejes, A. \& Köpsén, S. (2014) Vocational Teachers' Identity Formation through Boundary Crossing. Journal of Education and Work, Vol. 27. No. 3. pp. 265-283.

Gilbert, R. (2011) Professional Learning Flagship Program: Leading Curriculum Change, Literature Review. Melbourne, Australian Institute for Teaching and School Leadership.

Huberman, M., Grounauer, M. \& Marti, J. (1993) The Lives of Teachers. London, Cassell.

Kelchtermans, G. (1993) Getting the Story, Understanding the Lives: From Career Stories to Teachers' Professional Development. Teaching \& Teacher Education, Vol. 9. No. 5/6. pp. 443-456.

Kelchtermans, G. (2017) Studying Teachers' Lives as an Educational Issue. Teacher Education Quarterly, Vol. 44. No. 4. pp. 7-26.

Korthagen, F. (2004) In Search of the Essence of a Good Teacher: Towards a More Holistic Approach in Teacher Education. Teaching and Teacher Education, Vol. 20. No. 1. pp. 77-97.

Köpsén, S. (2014) How Vocational Teachers Describe Their Vocational Teacher Identity. Journal of Vocational Education and Training, Vol. 66. No. pp. 194-211.

Kyndt, E., Gijbels, D., Grosemans, I. \& Donche, V. (2016) Teachers' Everyday Professional Development: Mapping Informal Learning Activities, Antecedents, and Learning Outcomes. Review of Educational Research, Vol. 86. No. 4. pp. 1111-1150.

Looı, C.-K. \& Teн, L. W. (eds) (2015) Scaling Educational Innovations. Singapore, Springer.

Oktatási Hivatal. Köznevelési statisztika - KIR-STAT2016 Aggregátor rendszer. http:// www.kir.hu/stat16aggr [Letöltve: 2018. 06. 05.]

Oktatási Hivatal (2016) Útmutató a Mesterpedagógus fokozatot megcélzó minösitési eljáráshoz. https://www.oktatas.hu/pub_bin/dload/kiadvanyok/mesterpedagogus_utmutato.pdf [Letöltve: 2018. 06. 05.]

Robson, J., Bailey, B. \& Larkin, S. (2004) Adding Value: Investigating the Discourse of Professionalism Adopted by Vocational Teachers in Further Education Colleges. Journal of Education and Work, Vol. 17. No. 2. pp. 183-195.

Scheerens, J. (ed.) (2010) Teachers' Professional Development. Europe in International Comparison. An Analysis of Teachers' Professional Development Based on the OECD's Teaching and Learning International Survey (TALIS). Luxembourg, Office for Official Publications of the European Union.

Sikes, P., Measor, L. \& Woods, P. (1985) Teacher Careers: Crises and Continuities. London, Falmer. 
Villegas-Reimers, E. (2003) Teacher Professional Development: An International Review of the Literature. Paris, International Institute for Educational Planning.

Webster-Wright, A. (2009) Reframing Professional Development Through Understanding Authentic Professional Learning. Review of Educational Research, Vol. 79. No. 2.pp. 702-739. 